\title{
Assessment Of Smallholder's Furniture's And Carpenters On Bio-Deteriorating Attacks And Preservative Treatment To Wood In Ibadan Metropolis, Oyo State.
}

\author{
Adiji A.O' ${ }^{1}$;demola, A.A $A^{2}$; Orire L.T ${ }^{3}$ and Adebisi A.A ${ }^{4}$ \\ ${ }^{1,2,3,4}$ Forestry Research Institute of Nigeria, P.M.B. 5054, Jericho Hills, Ibadan, Oyo State \\ DOI: 10.29322/IJSRP.11.08.2021.p11623 \\ http://dx.doi.org/10.29322/IJSRP.11.08.2021.p11623
}

\begin{abstract}
This study assessed the awareness of smallholder's furniture and carpenter on wood biodeteriorating agents in Ibadan metropolis, Oyo state using questionnaires and interviews. Five local governments' areas were randomly selected within Ibadan metropolis. A total of 100 copies of questionnaire were administered to the respondents. Data collected were analyzed using descriptive statistics and correlation. All the sampled furniture makers and carpenters were male $(100 \%)$, while majority were married (85\%) and within the age category of $40-49$ years (44\%). Most of the furniture makers and carpenters had been into production for over 11 years $(40 \%)$. At one time or the other both the end user (54\%) and the furniture makers and carpenters (93\%) had problem with biodeteriorating agents. However, for both end user and the furniture makers as well as carpenters, termite and beetle attack is the most prominent biodeteriorating agents. Most of the respondents were aware of wood preservatives, however frequencies of use varies between rarely use $(73 \%)$ and often use $(27 \%)$. Result obtained shows that there is relationship between education, biodeteriorating attack, usage of preservative chemical and years of experience. It reveal that there is weak and positive correlation between education and incident of biodeteriorating attack to wood in their work place, education and usage of preservative chemical to treat wood. Also the result shows that there is strong and positive correlation between years of experience and the species of biodeteriorating agents that attack roofing part of a building and also complained by wood product user and incidence of biodeteriorating attacks in the wood workshops.
\end{abstract}

Index Terms- Decay, Wood, Termites, Utilization and Preservatives

\section{INTRODUCTION}

$\mathrm{W}$ ood is a biological, renewable and traditional building material which also serves as potential source of food for wood destroying agents such as bacteria, fungi, ants and termites (Schultz and Nicholas, 2002). As from heritage, wood is usually attacked or infested by biodegradating agent been a biological materials, thereby generating mainly loss of dimensional and structural stability (Alfieri et al, 2016). Despite the increasing demand for wood by small and large scale wood industries and the attendant loss of forest estates, the sector is also faced with the challenges of biodeteriorating agents causing great economic loss. In light of this, the devastating economic loss caused by biodeteriorating agents has become a major concern to scientists, policy makers, and most importantly small-scale furniture makers and carpenters in Nigeria. According to FAO (1987), furniture is mostly manufactured by small and medium size enterprises using simple technical expertise and technology with low capital input. Also, small and medium scale furniture production alone provides employment of about two million which constitute a reasonably large percentage of downstream wood users consume approximately $245,000 \mathrm{~m}^{3}$ of wood (FAO, 2005 and Odokonyero, 2005 ). Wood is believe to last long in service depending on how it is handle from the primary operation to the end users. Biodeteriorating agents can only attack wood when there is favourable condition. Very durable wood against biodeteriorating agents are now scarce and the available are not allow to mature before harvest and the use of lesser used wood species which are non-durable wood have now gaining recognition (Owoyemi, 2018). Incident and severity of biodegrading agent of wood has been confirmed in Nigeria (Adiji 2015; Adiji, et al., 2015; Owoyemi, et al 2016; Owoyemi, et al 2017). According to Adiji and Owoyemi, (2015), irrespective of the durability class of wood should be treated before use in service. Information on the handling techniques of wood during construction by smallholders' furniture and carpenters is one the key in addressing the protection of wood against biodeteriorating agents. Therefore, this work aim to assess the awareness of smallholder's' furniture and carpenter on wood biodeteriorating agents has it affects wood and wooden structures has limited published work is available in this area.

\section{Methodology}

Study Area

The study was conducted within Ibadan Metropolis in Oyo State, Nigeria. Ibadan is located approximately on Longitude $3^{\circ} 5^{1}$ East of the Greenwich Meridian and Latitude $7^{\circ} 23^{1}$ north of the Equator (NPC, 2006). According to NPC (2006), it population is about $1,338,659$. Also it is prominent in the production of cassava, cocoa, cotton, timber, rubber and palm oil (https://en.wikipedia.org/wiki/Ibadan). 


\section{Data Collection and Analysis}

One hundred (100) copies of structured questionnaire and oral interview were used to elicit information from furniture's maker and carpenters in the selected local government within Ibadan. At least twenty copies of the questionnaire were randomly administered on furniture's maker and carpenters from each of the selected local government in Ibadan Metropolis. Two urban local government; Ibadan North East and Ibadan Northwest and also three semi-urban local government; Ona-Ara, Egbeda, and Ido were randomly selected out of the eleven local government of Ibadan. 20 copies of questionnaire were administered in each selected local government. Information obtained through the questionnaire was supplemented with in-depth interview of the respondents. The data obtained were analyzed using descriptive statistics and correlation to establish relationship between education, year of experience and incidence of biodeteriorating attacks on wood.

\section{RESUlT AND DisCUSSION}

The result of the socio economics characteristic of the respondents is present in Table1. The result shows that all the respondents interviewed were males. This implies that men were fully in charge of furniture and carpentry works in the studies area, it agrees with the work of Alao and Kuje, (2012) and Babalola (2018) that men predominantly gender operating small-scale furniture. Most of the respondent are in the age group 40-49yr representing $44 \%$, follow by the age group $30-39 y$ rs with $32 \%$ and the age group $<30 \mathrm{yrs}$ of the respondents with $6 \%$ is the lowest. This assertion is in consonance with the submission of Aiyeloja $e t$ al. (2014) that the age category of small-scale furniture makers in Port Harcourt, Nigeria to fall between 31 and 50 years. It also shows that $85 \%$ of the respondents are married, $14 \%$ are single while $1 \%$ are divorcee. It further shows that $100 \%$ of the respondents are Yoruba and $91 \%$ of the respondent has secondary education and $1 \%$ has no formal education. It implies that most of the respondents dominantly are Yoruba and literate. The literacy level is encouraging because the respondents would be able to comprehend practical demonstrations made by skill development instructors in the process of skill acquisition capacity building. This is in consonance with Ajayi and Ojutiku (2008); Alao and Kuje, (2012) who stated that reasonable level of education will aid in the comprehension of practical demonstration by skill development instructors. However, it disagreed with the work of Babalola (2018) which submit that $36.1 \%$ of furniture producer had secondary education and $22.2 \%$ had primary education and $6.9 \%$ and $12.5 \%$ had tertiary and technical education respectively. The result also shows that $96 \%$ of the respondents are into Furniture and carpenter and $4 \%$ are only into Furniture making. It implied that furniture and carpenter are majorly practice by respondent and only few practice only furniture. The result of the monthly income, shows that $61 \%$ of respondent make between $\# 50,000$ - \#150,000 monthly, 24\% of the respondent make $<\# 50,000$.

Table1: Socioeconomic Characteristics of Respondents

\begin{tabular}{|l|l|l|}
\hline Variable & Frequency & Percentage \\
\hline Age group & & \\
\hline$<30$ & 6 & 6 \\
\hline $30-39$ & 32.0 & 32.0 \\
\hline $40-49$ & 44.0 & 44.0 \\
\hline$>50$ & 18.0 & 18.0 \\
\hline Total & 100.0 & 100.0 \\
\hline LGA & & \\
\hline Ona-Ara & 20 & 20 \\
\hline Egbeda & 20 & 20 \\
\hline Ibadan North East & 20 & 20 \\
\hline Ibadan North west & 20 & 20 \\
\hline Ido & 20 & 20 \\
\hline Total & 100 & 100 \\
\hline Marital status & & \\
\hline Single & 14 & 14 \\
\hline Married & 85 & 85 \\
\hline Divorced & 1 & 1 \\
\hline Total & 100 & 100 \\
\hline Gender & & \\
\hline Male & 100 & 100 \\
\hline Female & 0 & 0 \\
\hline Total & 100 & 100 \\
\hline Ethnic group & & \\
\hline Hausa & 0 & 0 \\
\hline Igbo & 0 & 0 \\
\hline & & \\
\hline
\end{tabular}




\begin{tabular}{|l|l|l|}
\hline Yoruba & 100 & 100 \\
\hline Education & & \\
\hline no formal & 1 & 1 \\
\hline Primary & 8 & 8 \\
\hline Secondary & 91 & 91 \\
\hline Tertiary & 0 & 0 \\
\hline Total & 100 & 100 \\
\hline occupation & & \\
\hline Furniture & 4 & 4 \\
\hline furniture and carpenter & 96 & 96 \\
\hline Total & 100 & 100 \\
\hline Income & & \\
\hline$<\# 50,000$ & 24 & 24 \\
\hline$\# 50,000-\# 150,000$ & 61 & 61 \\
\hline$>\# 150,000$ & 15 & 15 \\
\hline Total & 100 & 100 \\
\hline
\end{tabular}

Table 2 present the results of the respondent awareness on wood biodegrading agents as it affects wooden structure and wood. The result shows that $40 \%$ of the respondent has been into furniture making for about11-15yrs and about $32 \%$ has work more than 16 years while $40 \%$ of the respondent has been into carpentry work for about11-15yrs and about $31 \%$ has work for more than 16 years. It implied that most of the respondent have more years of experience in their field has they have been in the work for more than eleven years. It agreed with the work of Ajayi and Ojutiku, (2008) that longer years in a profession could contribute to the level of experience and skill put into quality of production. The result also revealed that $93 \%$ of the respondent has problem with biodeteriorating agent at one time or other at their workshop and termite attack been the most severe with $53 \%$ and beetle $41 \%$.
Also about $54 \%$ of respondent customers at one time or the other has complained of biodeteriorating agent, termite and beetle has been the most prominent biodeteriorating agent at 55\% and 38\% respectively. It implied that indeed they experience and are aware of the effects of biodeteriorating agents, however termite and beetle are very prominent in these attacks. Furthermore, 29\% of the respondent considered strength in choosing the wood species to work with while good finished, visual appearance, easy machining, durability, knowledge of the species and availability also informed choices of wood species used at 24\%, 17\%, $12 \%$, $10 \%, 6 \%$ and $2 \%$ respectively (Fig. 1). It implied that respondents has some little knowledge about the wood species they use.

Table 2: respondent awareness on wood bio-deteriorating agents attack

\begin{tabular}{|l|l|l|}
\hline Variable & Frequency & Percentage \\
\hline Are you into furniture work & 100 & 100 \\
\hline Yes & 0 & 0 \\
\hline No & 100 & 100 \\
\hline Total & 2 & 2.0 \\
\hline How many years are you into furniture & 26.0 \\
\hline $1-5 y r s$ & 26 & 40.0 \\
\hline $6-10 y r s$ & 40 & 32.0 \\
\hline $11-15 y r s$ & 32 & 100.0 \\
\hline$>16 y r s$ & 100 & \\
\hline Total & 94 & 94.0 \\
\hline Are you into carpentry work & 6 & 6.0 \\
\hline Yes & 100 & 100.0 \\
\hline No & \multicolumn{2}{|l|}{} \\
\hline Total & 2 & 2.0 \\
\hline How many years are you into carpenters & 21.0 \\
\hline $1-5 y r s$ & 21 & 46.0 \\
\hline $6-10 y r s$ & 46 & 31.0 \\
\hline $11-15 y r s$ & 31 & 100.0 \\
\hline$>16 y r s$ & 100 & 93.0 \\
\hline Total & 93 & \\
\hline Do you have problem of wood biodegrading agent(s) such as termites, fungi and beetle in your place of work \\
\hline Yes & 93 \\
\hline
\end{tabular}




\begin{tabular}{|l|l|l|}
\hline No & 7 & 7.0 \\
\hline Total of the wood & 100 & 100.0 \\
\hline $\begin{array}{l}\text { If yes, which of } \\
\text { biodegrading agents }\end{array}$ & & \\
\hline Termite & 53 & 53.0 \\
\hline Fungi & 6 & 6.0 \\
\hline Beetle & 41 & 41.0 \\
\hline Total & 100 & 100.0 \\
\hline
\end{tabular}

Has any of your customers complained of degradation of wood products sold to them due to attack by biodeteriorating agents

\begin{tabular}{|l|l|l|}
\hline Yes & 54 & 54.0 \\
\hline No & 46 & 46.0 \\
\hline Total & 100 & 100.0 \\
\hline If yes, which of the wood biodegrading agents was involved & \multicolumn{2}{|l|}{} \\
\hline Termite & 55 & 55.0 \\
\hline Beetle & 38 & 38.0 \\
\hline Fungi & 7 & 7.0 \\
\hline Total & 100 & 100.0 \\
\hline
\end{tabular}

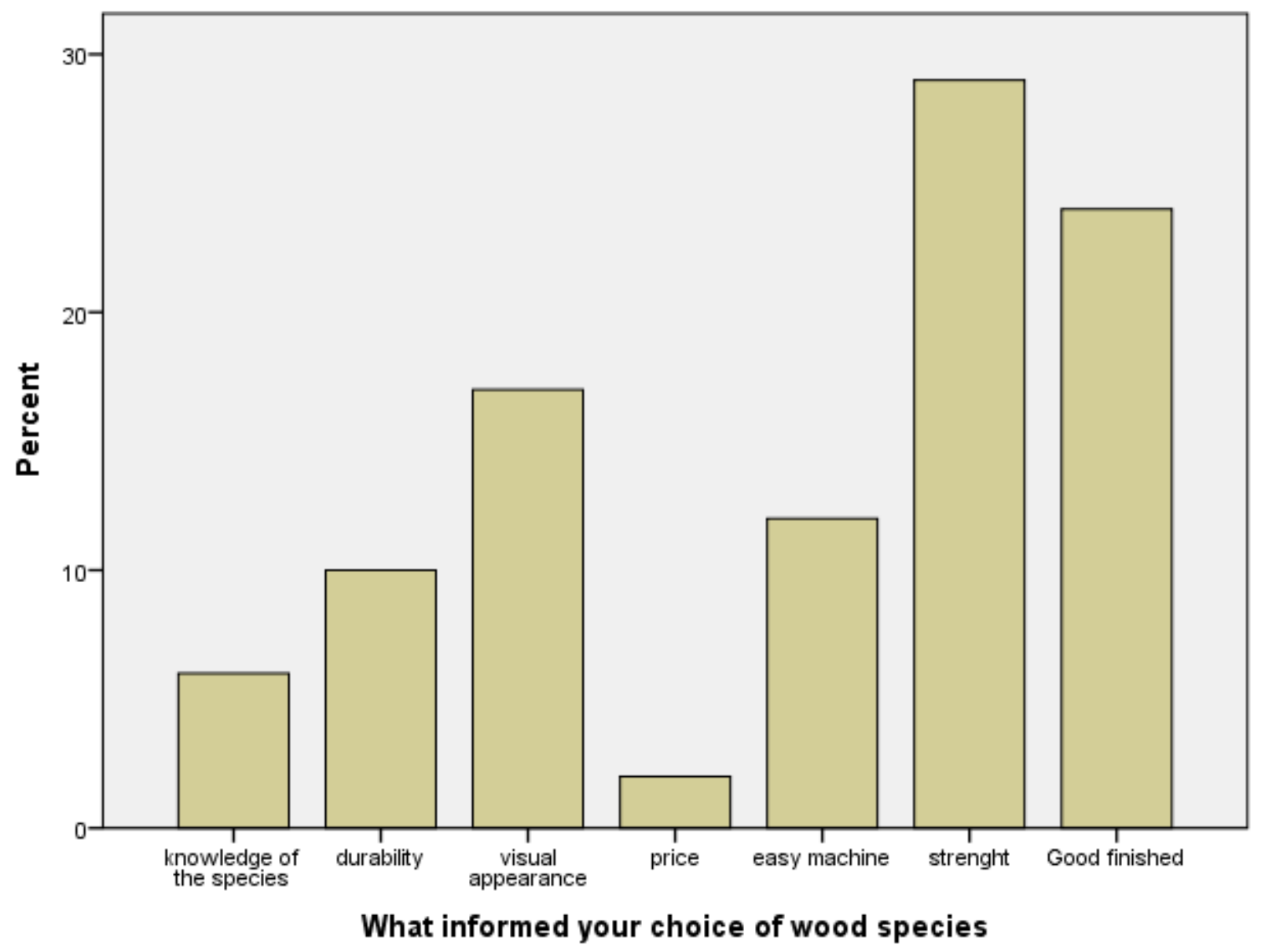

Figure 1: What informed choice of wood species

The result further revealed that $96 \%$ of respondent are aware of wood preservative chemical to treat wood against biodeteriorating agent. It implied that respondents are aware of wood preservative. It also shows that $27 \%$ of the respondent often use wood preservative chemical to treat their wood while $73 \%$ rarely treat their wood before delivery to the end user (table 4). It 
implied that in as much of their awareness of wood preservative, usage is still low. It also shows that DDforce been the mostly prefer wood preservative chemical at $86 \%$ for furniture work while soligum and black engine oil are used for carpentry work by respondents at $43 \%$ and $32 \%$ respectively (table 3 ). The result also revealed that $55 \%$ respondent uses brushing method as method of wood preservative chemical application while $45 \%$ preferred spraying method of application (table 4). It implied that brushing and spraying method is adopted for treating wood by the respondents, however this method is not the most effective as impregnating method but the initial cost of installation and the skill to operate the machine could impede them. It also shows that $76 \%$ of respondent does not know the benefits of preserving wood to the environment while $24 \%$ known the benefit. It implied that most of the respondents do know the benefit of preserving wood to environment, the reason could be their level of education as none of the respondent has more than secondary education. The result further revealed that $94 \%$ of respondent dry their wood before use or treatment with preservative chemical while $6 \%$ does not. The result of the frequency of drying wood before use or treatment with preservative chemical shows that only $29 \%$ of the respondent often dry there wood before use or treatment while
$71 . \%$ rarely dry there wood before use or treatment. Also $98 \%$ of respondent uses air drying as method of drying wood while $2 \%$ of respondent make use of conventional kiln drying method for drying wood. It implied that respondent dry their wood before use or treatment, however the frequency is very low as majority of the respondent rarely dry their wood because of the pressure by their customer to deliver on time and the air drying method employ respondents to dry the wood is a function climatic factors. The result of the challenges face by respondents in treating wood with preservative chemical shows that nose irritation is the most prominent with $36 \%$ while eye irritation, skin irritation, bad odour and technical knowhow with 22\%, 21\%, $20 \%$ and $1 \%$ respectively. It implied that nose irritation, eye irritation, skin irritation, bad odour and technical knowhow are the challenge face by respondent in the cause of wood treatment. The result further shows that $65 \%$ of the respondent suggested that awareness creation, $23 \%$ and $6 \%$ also submit that training and government policy respectively can promote wood preservation industry in Nigeria. It implied that respondent suggested that much awareness campaign, training and government policy in favour of wood protection should be initiated.

Table 3: Respondents respond on the wood preservative chemical use for furniture and carpentry work

\begin{tabular}{|l|l|l|l|l|l|}
\hline Furniture & Frequency & Percentage & Variable & Frequency & Percentage \\
\hline Variable & 86 & 86.0 & DDforce & 2 & 2.0 \\
\hline DDforce & & & & & \\
\hline Soligum & 5 & 5.0 & Best killer & 8 & 8.0 \\
\hline Sandsiller & 1 & 1.0 & Soligum & 43 & 43.0 \\
\hline Kerosene & 5 & 5.0 & Kerosene + salt & 3 & 3.0 \\
\hline Salt and water & 1 & 1.0 & Black engine oil & 32 & 32.0 \\
\hline Gamale 20 & 1 & 1.0 & Kerosene & 1 & 1.0 \\
\hline Termifos 20 EC & 1 & 1.0 & Petrol & 1 & 1.0 \\
\hline Total & 100 & 100.0 & Perfect killer & 1 & 1.0 \\
\hline & & & Gamale 20 & 2 & 2.0 \\
\hline & & & Sniper & 2 & 2.0 \\
\hline & & & Termifos 20 EC & 5 & 5.0 \\
\hline
\end{tabular}

Table 4: Respondent respond on wood preservative application

\begin{tabular}{|l|l|l|}
\hline Variable & Frequency & Percentage \\
\hline Are you aware of wood preservative chemical to treat wood & 96.0 \\
\hline Yes & 96 & 4.0 \\
\hline No & 4 & 100.0 \\
\hline Total & 100 & \multicolumn{2}{|l|}{} \\
\hline What is the frequency of use of wood preservative chemical to treat your wood \\
\hline
\end{tabular}




\begin{tabular}{|c|c|c|c|c|}
\hline Often & \multicolumn{2}{|l|}{27} & \multicolumn{2}{|l|}{27.0} \\
\hline Rarely & \multicolumn{2}{|l|}{73} & \multicolumn{2}{|l|}{73.0} \\
\hline Total & \multicolumn{2}{|c|}{100} & \multicolumn{2}{|l|}{100.0} \\
\hline \multicolumn{5}{|c|}{ Method of application of wood preservative chemical } \\
\hline Spraying & \multicolumn{2}{|c|}{45} & \multicolumn{2}{|l|}{45.0} \\
\hline Brushing & \multicolumn{2}{|l|}{55} & \multicolumn{2}{|l|}{55.0} \\
\hline Total & \multicolumn{2}{|l|}{100} & \multicolumn{2}{|l|}{100.0} \\
\hline \multicolumn{5}{|c|}{ Do you know the benefit of preserving wood to the environment } \\
\hline Yes & \multicolumn{2}{|c|}{24} & \multicolumn{2}{|l|}{24.0} \\
\hline No & \multicolumn{2}{|l|}{76} & \multicolumn{2}{|l|}{76.0} \\
\hline Total & \multicolumn{2}{|c|}{100} & \multicolumn{2}{|l|}{100.0} \\
\hline \multicolumn{5}{|c|}{ Do you want to be educated on how best to preserve wood } \\
\hline Yes & \multicolumn{2}{|c|}{98} & \multicolumn{2}{|l|}{98.0} \\
\hline No & \multicolumn{2}{|l|}{2} & \multicolumn{2}{|l|}{2.0} \\
\hline Total & \multicolumn{2}{|c|}{100} & 100.0 & \\
\hline What are the Challenges you fa & 1 treat & with $\mathrm{p}$ & ve chen & \\
\hline Eye irritation & 22 & & 22.0 & \\
\hline Nose irritation & 36 & & 36.0 & \\
\hline skin irritation & 21 & & 21.0 & \\
\hline Technical know how & 1 & & 1.0 & \\
\hline Bad odour & 20 & & 20.0 & \\
\hline Total & 100 & & 100.0 & \\
\hline Do you dry your wood before $u$ & r treat & rvati & & \\
\hline Yes & 94 & & 94.0 & \\
\hline No & 6 & & 6.0 & \\
\hline Total & 100 & & 100.0 & \\
\hline If yes, which method do you ad & n dry & & & \\
\hline air drying method & 98 & & 98.0 & \\
\hline conventional kiln drying method & 2 & & 2.0 & \\
\hline Total & 100 & & 100.0 & \\
\hline What is the frequency of drying & Ir wod & treatn & prese & chemica \\
\hline Often & & 29 & & 29.0 \\
\hline Rarely & & 71 & & 71.0 \\
\hline Total & & 100 & & 100 \\
\hline What do you think can be done & romo & ation & in Nige & \\
\hline Awareness & 65 & & 65.0 & \\
\hline Encourage wood industry & 3 & & 3.0 & \\
\hline Training & 23 & & 23.0 & \\
\hline Government policy & 6 & & 6.0 & \\
\hline None & 3 & & 3.0 & \\
\hline Total & 100 & & 100 & \\
\hline
\end{tabular}

Table 5: Correlations

\begin{tabular}{|l|l|l|l|}
\hline & $\begin{array}{l}\text { Do you have problem of } \\
\text { wood biodegrading } \\
\text { agent(s) such as termites, } \\
\text { fungi and beetle in your } \\
\text { place of work }\end{array}$ & $\begin{array}{l}\text { Species of wood } \\
\text { biodegrading agents that } \\
\text { attack roofing }\end{array}$ & $\begin{array}{l}\text { Do you use any wood } \\
\text { preservative chemical } \\
\text { to treat your wood }\end{array}$ \\
\hline Education of experience as & .072 & & .041 \\
\hline $\begin{array}{l}\text { Years' of } \\
\text { carpenters }\end{array}$ & & $.276^{* *}$ & \\
\hline $\begin{array}{l}\text { Has any of your customers } \\
\text { complained of degradation } \\
\text { of wood products sold to } \\
\text { them due to attack by } \\
\text { biodeteriorating agents }\end{array}$ & & & \\
\hline
\end{tabular}




\section{**. Correlation is significant at the 0.01 level (2-tailed).}

The result of correlation is presented in (table 5). It reveal that there is weak and positive correlation between education and incident of biodeteriorating attack to wood in their work place. It implied that there level of education does not affect the incidence of biodeteriorating agent attack. It also reveal that there is weak and positive correlation between education and usage of preservative chemical to treat wood. This implied that increases in the level of education lead to increase in the usage of preservative chemical usage to treat wood. The result also shows that there is strong and positive correlation between years of experience and the species of biodeteriorating agents that attack roofing part of a building. This implied that increase in their year of experience lead to increase in the different the type of biodeteriorating that attack the roofing part of the building. Furthermore, the results revealed that there is strong and positive correlation between complained by wood product user and incidence of biodeteriorating attacks in the wood workshops. This implied that increase in the incidence biodeteriorating agents attack in the wood workshop increases the complained the wood product user.

\section{CONCLUSION}

The awareness of smallholder's furniture and carpenter on wood biodeteriorating agents is a veritable tools in the sustainable management of wood and wooden products. Understanding the basic technique on how biodeteriorating agents attack wood and principle of the management of wood against the degradation. Also, knowing the nexus between wood preservation and climate change could also help in protecting wood and wooden production from biodeteriorating agents. It is therefore, recommended that rigorous awareness campaign and training should be created among smallholder's furniture and carpenters by nongovernmental organization (NGO), Community Based Organization (CBO) and government. Also, there is therefore need for government at all levels to encourage wood industries by creating enabling environment for the industries through credit facility loan and also initiate policy that will protect wood from biodeteriorating agents through wood preservation which in turn increase the service life of our wooden structures and in long run preserve (sustain) our trees that is, forest cover

\section{REFERENCES}

[1] Adiji, A.O. (2015): Prevalence and severity of Termites`attack on some selected indigenous Wood Species in Ondo State, Nigeria. A thesis submitted for the award of M. Agric.Tech. Federal University of Technology, Akure. Unpublished.

[2] Adiji, A.O and Owoyemi, J.M. (2015): Assessment of the severity of termites attack on selected wood species in Ondo State, Nigeria. Paper presented at the 8th School of Agriculture and Agricultural Technology, Federal University of Technology, Akure Conference. 18th - 20th March, 2015.

[3] Aiyeloja A. A.,Oladele A. T., and Ozoemena, C. S. (2014): Socio- economic Analysis of wood furniture production in Rivers State. Journal of Forest Resources30:126-135

[4] Ajayi, O. and Ojutiku, R.O. (2008): Economic evaluation of artisan fishermen among rural folks in Katcha Local Government Area of Niger State, Nigeria. Journal of Agricultural Research and Policies, 3(1): 102-106

[5] Alao, J.S. and Kuje, E. D. (2012): Economics of Small-scale Furniture Production in Lafia Metropolis, Nasarawa State Nigeria. Journal of Economics, 3(1): 49-54

[6] Babalola, F. D. (2018): Factors influencing operations of small-scale wooden furniture enterprise in Ilorin, Kwara state, Nigeria. Journal of Forestry Research and Management. Vol. 15(1).100-113; 2018, ISSN 0189-8418

[7] https://en.wikipedia.org/wiki//badan. Accessed 3rd May, 2021

[8] FAO (1987): Small-Scale Forest Based Processing Enterprises. FAO, Rome, P. 246.

[9] FAO (2005): Micro Finance and Forest Based Small-Scale Enterprises. FAO, Rome, P. 246

[10] NPC (2006): National Population Commission 2006, Abuja, Nigeria

[11] Odokonyero, G. (2005): Forest Harvesting Case study, Pit sawn Timber Production from Natural Forests of Uganda, FAO, Rome.

[12] Owoyemi, J.M, Adiji, A.O and AladejanaJ.T (2017): Resistance of Some Indigenous Tree Species to Termite Attack in Nigeria. Journal of Agricultural and Urban Entomology, Jan 2017: Vol. 33, Issue 1, pg(s) 10-18 dol:10.3954/1523-5475-33.1.10. Published bythe South Carolina Entomological Society.

[13] Owoyemi, J.M. and Akintomide, T.O. (2018): Assessment of Density and Anatomical

[14] Properties of Nigerian Grown Cocos nucifera Wood, Applied Tropical Agriculture Volume 23, No. 1, 132-138, 2018. @ A publication of the School of Agriculture and Agricultural Technology, The Federal University of Technology, Akure, Nigeria

[15] Owoyemi J.M., Adiji A.O., Aladejana J.T., Olawale O.E. and Oladapo O.D. (2016):

[16] Termiticidal Effect of Bitumen and Creosote Oil Treatments on Selected Nigerian Wood Species. Paper presented at the 47th Annual meeting of the International Research Group on Wood Protection (IRG47) 15-19 May 2016, Lisbon Portugal.

\section{AUTHORS}

First Author - Adiji A.O, Forestry Research Institute of Nigeria, P.M.B. 5054, Jericho Hills, Ibadan, Oyo State

Second Author - Ademola, A.A, Forestry Research Institute of Nigeria, P.M.B. 5054, Jericho Hills, Ibadan, Oyo State

Third Author - Orire L.T, Forestry Research Institute of

Nigeria, P.M.B. 5054, Jericho Hills, Ibadan, Oyo State

Fourth Author - Adebisi A.A, Forestry Research Institute of Nigeria, P.M.B. 5054, Jericho Hills, Ibadan, Oyo State

Corresponding author: adijiayodeji@gmail.com, 07038874432 